\title{
Optimization of Products Transportation and Distribution Network
}

\author{
${ }^{1}$ Akpan, W. A . ${ }^{2}$ Awaka- Ama, E.J. ${ }^{3}$ Ikrang, E.G. \\ ${ }^{1}$ Mechanical and Aerospace Engineering Department, University of Uyo. Nigeria \\ 2 Mechanical and Aerospace Engineering Department, University of Uyo. Nigeria \\ 3 Agric/ Food Engineering Department, University of Uyo, Nigeria
}

\begin{abstract}
This research work focuses on the problem of transportation and distribution of products by a manufacturing company. The aim of the study is to determine the least cost of transportation and distribution of products by a firm. A popular brand in the food and beverage industry in Nigeria was selected for a case study. Two of it plants in the southern part of the country were investigated. Distribution centres located at Umuahia, Awka and Asaba are the destinations. Data of the supply from the two plants to the three centres, demand per period from each of the destinations and the cost of transportation from plant to each destination were obtained from the data base of the company. The analysis of the data using Vogel's linear programming model reveals a total savings of Nine million, seven hundred and sixty one thousand, nine hundred and eighty-five naira (\# 9,761,985.00). The research shows that Vogel's approximation method is effective in solving practical products transportation and distribution problems.
\end{abstract}

Keywords.; Products transportation, distribution, network, optimization, Vogel's method.

\section{INTRODUCTION}

Transportation is the movement of people, animals and goods from one location to another. Distribution is the process of making a product or service available for use or consumption by a consumer or business user, using direct means or using indirect means with intermediaries.

A product according is anything that can be offered to a customer for attraction, acquisition use or consumption that might satisfy a want or need.

There are various modes of transportation of products depending on size and urgency. Road transport is cheap, convenient and one of the most flexible modes of transport. It is subject to heavy delays. It sets limit to and restrict the movement of certain heights, weights and lengths of products. Rail transport is speedy, environmentally friendly and not always subject to congestion or delays. However, it is inflexible. Airfreight is without doubt the fastest to transport products across distances but is expensive and not eco-friendly. Airfreight is carried by cargo airlines as well as scheduled passenger aircraft.

Shipping by sea is relatively cheap, particularly if large volumes are sent. It is slow, and fairly inflexible with few ports and further arrangements must be made to move the products inland. Sea freight vessels are made up of cargo ships, bulk carriers, tankers -for liquids, roll-on or roll-off vessels. There are two types of shipping: liner vessels which operate on fixed routes with fixed schedules and
Tramp vessels which operate entirely according to the demand of the client.

Couriers are business experts that operate fast, reliable and secured services. Couriers are expensive and only cost effective over short distances.

Factors that influence the distribution network design include customers' needs and the cost of meeting those needs.

Goods and passengers movement in Nigeria are performed mainly by road with the railway and inland waterways playing significant, but less important roles. International freight movement is principally by sea while air transportation is mostly patronized by well placed individuals.

The supply chain is the chain links to each element of the manufacturing and supply process, from raw materials to end users. The supply chain consists of all parties that are directly or indirectly involved in fulfilling customer demands. These include the manufacturer, supplier, transporter, wholesaler, retailers and customers [1]. The scope of supply chain can be defined in terms of the number of firms involved in the supply chain and the function involved. Dimension to consider include length of the supply chain and the numbers of suppliers and customers at each level. It is therefore clear that transportation and distribution are sub set of supply chain. This research work focuses on these two elements. The transportation model has been used in movement of goods from plant to warehouse, resource allocation, assignment of work to machines, capital budgeting and deployment of warship to locations [2].

Linear programming model is a mathematical formulation in which the objective function is linear. Murthy [3] defined linear programming model as a formulation for the allocation of scarce or limited resources to competing products or activities under such assumption as certainty, linearity, fixed technology and constant profit per unit. The transportation model is a special class of linear transportation problem in which the objective is to transport a homogeneous commodity from various origins or factories to different destinations or markets at a minimum cost. There are few methods of solving transportation problems under linear programming. This include simplex method, North west corner Method, Least cost method and Vogel's approximation method (VAM). According to Murthy [3] Vogel' approximation method has the potential to give the most optimal solution and will be 
used in this study. Other researches on product transportation are found in: [4], [5], [6], [7], and [8].

\section{METHODOLOGY}

Two plants of a production company in food and beverages located in Rivers state and Imo state -Nigeria were selected for the case study and call sources. Each centre- Umuaha in Abia state, Awka in Anambra state and Asaba in Delta state were chosen and call destinations. Quantities of products supplied from these two plants to the three demand centres were obtained. The costs of transportation from the source to the destinations were also obtained and this data were inputs to Vogel's approximation methodology for computation and the determination of the optimum product allocation to these centres.

\subsection{Model Formulation}

Minimise the objective function $\mathrm{Z}$

$$
Z=a x_{11}+b x_{12}+c x_{13}+d x_{21}+e x_{22}+f x_{23}
$$

Where $\mathrm{a}, \mathrm{b}, \mathrm{c}, \mathrm{d}$, e and $\mathrm{f}$ are transportation costs and;

$$
x_{11}, x_{12}, x_{13}, x_{21}, x_{22}, x_{23} \text { are quantities supplied. }
$$

\section{Subject to}

$$
\begin{array}{r}
X_{11}+X_{12}+X_{13}=A_{1} \\
X_{21}+X_{22}+X_{23}=A_{2}
\end{array}
$$

$$
X_{11}+X_{21}=B_{1}
$$$$
X_{12}+X_{22}=B_{2}
$$$$
X_{13}+X_{23}=B_{3}
$$

Where $X_{i j}$ is the quantity of products transported from supply point $\mathrm{i}$ to destination $\mathrm{j}$

( $i=1,2$ are Port Harcourt and Owerri plant) and $j=1,2.3$ are Umuahia, Awka and Asaba demand centre points)

$A_{1}$ and $A_{2}$ are Port Harcourt and Owerri supply capacities respectively.

$B_{1}$ and $B_{2}$ are the demand requirements at one Umuahia, Awka and Asaba demand centre points

\subsection{INPUT DATA}

Tables $1,2,3$ and 4 show the input data to solve the Vogel's algorithm.

Table 1 Cost of transportation from Port Harcourt plant to each of the distribution centres

\begin{tabular}{|l|l|}
\hline Distribution Centre & Cost of Transport per truck x ( $\mathrm{A} 100)$ \\
\hline Asaba & 623 \\
\hline Awka & 612 \\
\hline Umuahia & 578 \\
\hline
\end{tabular}

Table 2 Cost of transportation from Owerri plant to each of the distribution centres

\begin{tabular}{|l|l|}
\hline Distribution Centre & Cost of Transport per truck x ( 100$)$ \\
\hline Asaba & 578 \\
\hline Awka & 576 \\
\hline Umuahia & 576 \\
\hline
\end{tabular}

Table 3 Quantity of products supplied to the three centres

\begin{tabular}{|l|l|}
\hline Distribution Centre & Quantity demanded (Trucks) \\
\hline Asaba & 565 \\
\hline Awka & 470 \\
\hline Umuahia & 525 \\
\hline
\end{tabular}


Table 4 Quantity of product demanded at centres

\begin{tabular}{|l|l|}
\hline Distribution Centre & Quantity demanded (Trucks) \\
\hline Asaba & 623 \\
\hline Awka & 612 \\
\hline Umuahia & 578 \\
\hline
\end{tabular}

Table 5 shows a tableau representation prior to the solution of the problem.

Table 5

\begin{tabular}{|l|l|l|l|l|}
\hline Distribution cost & Umuahia (N 100) & Awka (N 100) & Asaba (\#100) & Supply(trucks) \\
Demand & & & & \\
\hline Port Harcourt & & & & \\
\hline Owerri & 578 & 619 & 623 & 936 \\
\hline Demand & & & & \\
& 576 & 576 & 578 & 624 \\
\hline
\end{tabular}

\section{Vogel's method and results}

Step 1 Creation of a dummy row to balance supply and demand as shown in table 6

Table 6 Balance supply and demand by creating a dummy row

\begin{tabular}{|l|l|l|l|l|}
\hline $\begin{array}{l}\text { Plants, Dummy and } \\
\text { Demand }\end{array}$ & Umuahia & Awka & Asaba & Supply \\
\hline Port Harcourt & 578 & 619 & 623 & 936 \\
\hline Owerri & 576 & 576 & 578 & 624 \\
\hline Dummy & 0 & 0 & 0 & 520 \\
\hline Demand & 694 & & 754 & Total=2080 \\
\hline & & & \\
\hline
\end{tabular}

Step 2: The penalties for each row and column are written. This obtained by subtracting the least cost from the second least cost in each row and column. The column or row with the highest penalty will receive maximum allocation as shown in table 7 .

Table 7

\begin{tabular}{|l|l|l|l|l|l|}
\hline & Umuahia & Awka & Asaba & Supply \\
\hline & 578 & 619 & 623 & 936 & Penalty \\
\hline & 576 & 576 & 578 & 624 & 0 \\
\hline Dummy & 0 & 0 & 0 & 764 & 520 \\
\hline Demand & 694 & 576 & 578 & Total=2080 & 0 \\
\hline Penalty & 576 & & & \\
\hline
\end{tabular}

Column 3 has the highest allocation with 578 and so the least cost cell (3.3) is satisfied with maximum allocation of 520. This eliminates row 3 and new penalties are taken resulting in the result of table 8

Table 8

\begin{tabular}{|l|l|l|l|l|l|}
\hline & Umuahia & Awka & Asaba & Supply & Penalty \\
\hline & 578 & 619 & 623 & 936 & 41 \\
\hline & 576 & 576 & 578 & 624 & 0 \\
\hline Demand & 694 & 632 & 234 & Total=1.560 & \\
\hline
\end{tabular}

Column 3 again has the highest penalty of 45 . The least cot cell $(3,2)$ is satisfied with allocation of 234 thereby eliminating column 3 . It reduces to the results in table 9. 
Table 9

\begin{tabular}{|l|l|l|l|l|}
\hline & Umuahia & Awka & Supply & Penalty \\
\hline & 578 & 619 & 936 & 41 \\
\hline & 576 & 576 & 390 & 0 \\
\hline Demand & 694 & 632 & Total=1,326 & \\
\hline Penalty & 2 & 43 & & \\
\hline
\end{tabular}

New penalties are taken and allocation made as previously done. This eliminates row 2 yielding the tabulation in table 10.

Table 10

\begin{tabular}{|l|l|l|l|l|}
\hline & Umuahia & Awka & Supply & Penalty \\
\hline & 578 & 619 & 936 & 41 \\
\hline Demand & 694 & 242 & Total=936 & \\
\hline
\end{tabular}

The cell with the least cost $(1,1)$ is allocated maximum allocation (694) reducing it to the form shown in table 11.

Table 11

\begin{tabular}{|l|l|l|}
\hline & Umuahia & Supply \\
\hline & 619 & 242 \\
\hline Demand & 242 & Total $=242$ \\
\hline
\end{tabular}

Step 3: Table 12 below presents a summary of the allocations made- indicated in brackets to the respective cost cells.

Table 12

\begin{tabular}{|l|l|l|l|l|}
\hline & Umuahia & Awka & Asaba & Supply \\
\hline Port Harcourt & $578(694)$ & $619(242)$ & 623 & 936 \\
\hline Owerri & 576 & $576(390)$ & $578(234)$ & 624 \\
\hline dummy & 0 & 0 & $0(520) 754$ & 520 \\
\hline Demand & 694 & 632 & & Total=2,080 \\
\hline
\end{tabular}

Step 4: The table of basic solution is drawn. Table 13 shows the optimal cost of transporting the products to their destinations with the creation of a dummy supply centre within these three centres of Port Harcourt, Umuahia and Asaba.

Table 13

\begin{tabular}{|l|l|l|l|}
\hline From & To & Quantity( number of trucks) & Cost(x-N 100) \\
\hline Port Harcourt & Umuahia & 694 & $578 \times 694=401,132$ \\
\hline Port Harcourt & Awka & 242 & $619 \times 242=149,798$ \\
\hline Owerri & Awka & 390 & $576 \times 390=224,640$ \\
\hline Owerri & Awka & 234 & $578 \times 243=135,252$ \\
\hline Total(\#) & & 91,0822 \\
\hline
\end{tabular}

\section{CONCLUSIONS AND RECOMMENDATIONS}

The cost of product transportation has been reduced from $\mathrm{N}$ $100,844,185$ (One hundred million, eight hundred and forty-four thousand naira) to $\mathrm{N} 91,082,200$ (Ninety one million, eighty two thousand, two hundred naira) with a saving of $\mathrm{N} 9,761,985$ (Nine million, seven hundred and sixty-one thousand, nine hundred and eighty five naira) from two plants to three centres by using this method. Vogel's approximation method is hereby recommended for application in these industries. The burden of computation can be reduced by using computer algorithm and is recommended for future work.

\section{REFERENCES}

[1] Chopera, S. (2001) Designing the distribution Network in a supply Chain. Kellog School of Management, pp 1-42

[2] Nyong, M.O. (2005) Management Science: An Operations Research Emphasis in Economics and Business. Clear Lines Publication, Calabar, Cross River State.

[3] Murthy, P.R. (2007) Operation Research 2 Ed. New age international limited. Pp 141-211
[4] Kandekar, S. (2012): Optimizing the Distibution Channels-A Case Study of Timber Product Distribution Channel. Linkoping University, pp 37-59

[5] Kerukoglu, S.(2010) An Improved Vogel's Approximation Method for the Transportation Problem

[6] Singh, S. Dubey, G.C. Shriivastava, R. (2012a) "A Various Method to Solve the Optimality for the

[7] Transportation Problem'.' International Journal of Mathematical Engineering and Science Vol. 1 Issue 4

[8] Singh, S. Dubey, G.C. Shriivastava, R. (2012b). ' Optimization and Analysis of Some Variants through Vogel's Approximation Method (VAM)'. IOSR Journal of Engineering Vol.2 Issue 9, pp 20-30

[9] Zihiaris, S (2000) Sipply Chain Management- EC funded project Available

[Online]www.adi.pt.docs/innoregio_supp_management_pdf( $14^{\text {th }}$ May 2015) 